\title{
THE SECOND AMENDMENT: A DIALOGUE
}

\author{
Don B. Kates, JR.* \\ I \\ INTRODUCTION
}

A recent article in the National Rifle Association's magazine by Professor Stephen Halbrook, ${ }^{1}$ whose book on the second amendment has also just appeared, ${ }^{2}$ reviles certain conclusions of my article, Handgun Prohibition and the Original Meaning of the Second Amendment, published in the Michigan Law Review (the Michigan article) ${ }^{3}$ as "Orwellian Newspeak." Having due regard for both the historical evidence cited in Professor Halbrook's article and the importance of his previous work in the area, ${ }^{4}$ I have invited him to set forth his disagreement in greater detail here. At the same time, I take the opportunity to summarize my revised views as to the kinds of gun controls which the second amendment allows. First, however, I offer some discussion of a question which, although essentially preliminary, has almost completely monopolized modern discussion of the second amendment.

\section{II}

\section{The Individual Right vs. State's Right Controvery}

Two fundamentally competing views of the second amendment have dominated contemporary legal literature. The antithesis of the belief in an individual right to keep and bear arms, as espoused by Professor Halbrook, ${ }^{5}$ is the "state's right" view, which holds that the second amendment guarantees nothing to the people and protects only the states' right to muster and arm

Copyright (C) 1986 by Law and Contemporary Problems

* Yale Law School, LL.B. (1966). Partner, Benenson, Kates \& Hardy (San Francisco office): Of Counsel, Hallesey \& Johnson, San Francisco. The author wishes to thank the following for their assistance: Professor William Van Alstyne (Law, Duke University), Professor Joyce Malcolm (History, Bentley College), Ms. S. Byrd and Mr. C. Spector, Berkeley, California, and Ms. P. Kates, San Francisco, California.

1. Halbrook, To Bear Arms for Self-Defense: Our Second Amendment Heritage. Am. Rifleman, Nov. 1984 , at 28 .

2. S. Halbrook, That Every Man Be Armed: The Evolution of a Constitutional Right (1984).

3. Kates, Handgun Prohibition and the Original Meaming of the Second Amendment. 82 Micn. L. Rex. 204 (1983).

4. See, e.g., Halbrook, To Keep and Bear Their Privale Arms: The Adoption of the Second Amendmem 1787-1791, 10 N. KY. L. Rev. 13 (1982) |hereinafter cited as Halbrook, Private .trmsi: Halbrook. The Jurisprudence of the Second and Fourteenth .Amendments, 4 Geo. Mason U.L. REv. 1 (1981).

5. See, e.g., Halbrook, What the Framers Intended: A Linguistic Analysis of the Right to "Bear .Imms." LaW \& Contemp. Probs., Winter 1986, at 151. 
formal military units. ${ }^{6}$ It is surprising that the state's right view has so dominated modern legal discussion of the amendment, ${ }^{7}$ since that view cannot survive serious or disinterested analysis. Lest that statement seem hyperbolic, the overwhelming evidence must briefly be considered: The state's right concept is a twentieth-century invention which was totally unknown to courts and commentators from the time of the amendment's enactment through the end of the nineteenth century; 8 the two written interpretations available to Congress before it voted on the amendment described the amendment as confirming in "the people of the United States who are peaceable citizens" the right to keep "their own arms," "their private arms"; 9 contemporary materials show congressmen, and others among the founding fathers, describing the right to arms as an elementary "human right," "respected personal liberty," "essential and sacred"-and referring to it interchangeably with such other "private rights" as freedom of religion and expression; 10 the entire corpus of political philosophy known to the Founding Fathers taught them to promote an armed citizenry as the hallmark of, and indispensible precondition for, maintaining individual liberty and republican

6. See, e.g., Weatherup, Standing Armies and Armed Citizens: An Historical Analysis of the Second Amendment, 2 Hastings Const. L.Q. 961 (1975), as well as the other articles cited in Kates, supra note 3, at 207 n.13, and Shalhope, The Armed Citizen in the Early Republic, Law \& Contemp. Probs., Winter 1986, at 125,125 n.2.

7. In ascribing dominance to the state's right view, I am speaking not of the literal quantity of scholarly literature, but rather of that view's espousal by arbiters like the American Bar Association and the American Civil Liberties Union. Actually, the number of law review articles favoring the individual right approach slightly exceeds those favoring the state's right view. In .recent years this numerical discrepancy has been particularly great. Moreover, the individual right view has alwavs prevailed among historians and philosophers. See citations in Shalhope, supra note 6, at 125 n.2, and Kates, supra note 3, at 206 n.10, 207-08 nn.12-15.

8. Kates, supra note 3 , at 240-47. Among the most remarkable aspects of the state's right literature is the unblushing mendacity with which it treats 19th-century decisions. Typical is J. Alviani \& W. Drake, Handgun Control: Issues and Alternatives 9 (1975) (U.S. Conference of Mayors Handgun Control Project), citing the following 19th-century cases as holding that "personal self-protection was never an issue in the adoption of the Second Amendment": United States v. Cruickshank, 92 U.S. 588 (1875), Presser v. Illinois, 116 U.S. 252 (1886), and Miller v. Texas, 153 U.S. 535 (1894). In fact, all any of these cases did was apply to the second amendment (as well as to the first and fourth amendments) the standard 19th-century doctrine that no part of the Bill of Rights was applicable against the states. Far from denying that the amendment guarantees individual gun ownership, these decisions clearly affirmed that precisely such a guarantee does exist-but only against federal legislation. See Kates, supra note 3, at 246-47. Alviani and Drake go so far as to falsify a quotation from the Cruickshank case, bowdlerizing it to eliminate language which would have impugned the misconstruction they sought to put upon it. See J. Alviani \& W. Drake, supra, at 9.

9. Kates, supra note 3 , at 224. These interpretations were published as two newspaper commentaries, one Federalist, the other anti-Federalist-illustrating at once the bipartisan support that the individual right to arms enjoyed and the total absence from contemporary thought that the amendment's language could be interpreted otherwise. Both commentaries appeared in newspapers across the country, including rival Federalist and anti-Federalist newspapers in Philadelphia where the first Congress was sitting. The Federalist commentary was written by an ally of Madison and received his imprimatur. See generally Halbrook, Private Arms, supra note 4, at 29, 33.

10. See Kates, supra note 3, at 221-23, 235; Halbrook, Private Arms, supra note 4, at 18. It bears emphasis that for these and many other points, my Michigan article is heavily indebted to Professor Halbrook's original research-notwithstanding any disagreements he may have with the use I have made of it. 
institutions; " the writings of the Founding Fathers themselves reveal what one intellectual historian has described as an "almost religious" veneration for "the relationship between men and arms"; 12 the "right" referred to in the second amendment was that which the Founders knew from their own law and from Blackstone's characterization of the right to arms as one of the five preeminent and "absolute rights of individuals" at common law;13 "militia," as used in the amendment and in the eighteenth century generally, referred not to some kind of military unit, but to a system under which virtually every male of military age was legally required to possess his own arms for personal defense, crime prevention, and community defense; ${ }^{14}$ and interpreting the amendment as guaranteeing a state right to possess armed forces produces a gratuitous conflict with article I, section 10, clause 3 of the United States Constitution, which forbids the states from doing so without express congressional consent.

More telling yet is the grotesque inconsistency of the state's right interpretation with the actual text of the Bill of Rights:

To accept such an interpretation requries the anomalous assumption that the Framers ill-advisedly used the phrase "right of the people" to describe what was being guaranteed when what they actually meant was "right of the states." In turn, that assumption leads to a host of further anomalies. The phrase "the people" appears in four other provisions of the Bill of Rights, always denoting rights pertaining to individuals. Thus, to justify an exclusively state's right view, the following set of propositions must be accepted: (1) when the first Congress drafted the Bill of Rights it used "right of the people" in the first amendment to denote a right of individuals (assembly); (2) then, some sixteen words later, it used the same phrase in the second amendment to denote a right belonging exclusively to the states; (3) but then, fortysix words later, the fourth amendment's "right of the people" had reverted to its normal individual right meaning; (4) "right of the people" was again used in the natural sense in the ninth amendment; and (5) finally, in the tenth amendment the first Congress specifically distinguished "the state's" from "the people," although it had failed to do so in the second amendment. ${ }^{15}$

III

To What Extent Does the Second Amendment Preclude "Gun Control"?

The conclusion that the second amendment guarantees individuals the right to possess arms for "self-defense" against crime, oppression, and attack by foreign foes is inevitable ${ }^{16}$ Yet, it should be clear that reasonable gun 33.

11. See Kates, supra note 3, at 230-35 (and sources cited therein); Shalhope, supra note 6, at 126 -

12. Asbury, The Right to Keep and Bear Arms in America: The Origins and Application of the Second Amendment to the Constitution (1974) (unpublished doctoral thesis in history. University of Michigan) (available in University of Michigan Graduate Library).

13. Kates, supra note 3, at 240; see also id. at 217 \& n.53, 241 \& n.156, 258 \& nn.234-235.

14. Id. at $214-18$.

15. Id. at 218.

16. As indicated infra note 24, the literal phrase "self-defense" may, at least among 181hcentury lawyers and lawmakers, have been used in the highly limited and pejorative sense of the carly common law. But the sanctity with which the Founders held the concept of what we would coday describe as self-defense can scarcely be exaggerated. Indeed, the confusion and controvers! which 
controls are no more foreclosed by the second amendment than is reasonable regulation of speech by the first amendment. For instance, freedom of speech has not been thought to preclude laws against solicitation of murder-or even permit requirements for parades or speeches, so long as applications are speedily processed according to fixed, nondiscriminatory criteria which are designed to effectuate, without hindering or nullifying, the basic right involved. ${ }^{17}$ The following examples suggest specific gun controls which the second amendment would allow.

\section{A. To Whom Does the Right Extend?}

In classical republican political philosophy, the concept of a right to arms was inextricably and multifariously tied to that of the "virtuous citizen." Free and republican institutions were believed to be dependent upon civic virtu which, in turn, depended upon each citizen being armed-and, therefore, fearless, self-reliant, and upright. Since possession of arms was the hallmark of a citizen's independence, the ultimate expression of civic virtu was his defensive use of arms against criminals, oppressive officials, and foreign enemies alike. ${ }^{18}$ One implication of this emphasis on the virtuous citizen is that the right to arms does not preclude laws disarming the unvirtuous citizens (i.e., criminals) or those who, like children or the mentally unbalanced, are deemed incapable of virtue. ${ }^{19}$

\section{B. What Kinds of Arms Are Within the Amendment's Guarantee?}

Although my Michigan article suggested several limiting principles as to the kinds of arms contemplated, the fact that they largely overlap, as well as space considerations, dictate discussing only two types of limitations. First, the common law right to bear arms excluded "dangerous or unusual" arms whose mere display by an individual would naturally terrify his neighbors, a limitation which was preserved in the second amendment. ${ }^{20}$ Thus, the amendment should not be interpreted as guaranteeing individual possession of weapons such as machine-type guns, flamethrowers, artillery, and atomic weapons, whose use, even in strict self-defense, would quite obviously menace one's neighbors. Based upon suitable legislative findings, this qualification

exists over the amendment's meaning today is, I think, largely attributable to our ambivalence about what the Founders' heritage viewed as the right from which all others sprang. Even Hobbes had proclaimed self-defense as a right of nature so basic as to be incapable of waiver. English and colonial religious thinkers held that self-defense was not merely a right but a duty-refusal to use force against one who would take life being tantamount to suicide and further condemned for leaving the attacker free to prey on others. From Locke, the Founders learned to conceive of tyrants as felons whom the virtuous citizen should resist just as he would resist any other species of robber. See Kates, supra note 3, at 230.

17. Compare Poulos v. New Hampshire, 345 U.S. 395 (1953) with Niemotko v. Maryland, 340 U.S. 268 (1951) and Kunz v. New York, 340 U.S. 290 (1951).

18. See generally Kates, supra note 3, at 231-33 (and authorities cited therein); Shalhope, supra note 6 .

19. See Kates, supra note 3, at 266 (citing formulations in which the Founders explicitly limited the right to law-abiding citizens).

20. See id. at 261 . 
might well justify banning armor-piercing bullets, and-at least in urban and other densely populated areas-high-powered rifles, both of which are so highly penetrative that they will likely pass through a criminal attacker and go on, even through walls, to menace innocents beyond. ${ }^{21}$

An additional, but even broader, exclusionary principle has been obscured by a major difference between the modern perspective on the function of arms and the perspective of the Founders. In contemporary society, the use of arms is strictly dichotomized between personal defense and "the common defense," the latter being accomplished by soldiery armed with specialized military weaponry inappropriate to civilian possession or use. Such a dichotomy would never have occurred to the Founders, whose army was both totally inadequate ${ }^{22}$ and armed with weaponry indistinguishable from the individual's. By necessity and by law, each individual was required to perform the duties of both soldier and law enforcer (there were no police) with his own private arms. ${ }^{23}$ As the Founders would have conceived it, the yeoman repelling intruders from his dwelling was, with the same arms, acting both in his own and the common defense-whether those intruders were felons, oppressive officials, or enemy soldiers. ${ }^{24}$

21. In addition to the long gun's much greater over-penetration and lethality, it is much more subject to accidental discharge $g$ than a handgun would be when kept loaded in home or office for self-defense. See Kates, supra note 3, at 261-64.

22. As of the mid-1780's the United States Army consisted of 800 men scattered along the frontier in tiny posts and forts. Although parsimony played its part, this highly limited military establishment can largely be attributed to the profound distrust, amounting at times to antagonism, Americans showed toward the military until comparatively recent times. During the Indian Wars of the late 19th century, the Army's size remained fixed by law at 25,000 enlisted men-a proportion of soldiery to citizenry considerably below even that of a century before. As late as 1939, the Army of the United States was less numerous than that of Yugoslavia. R. WEIGLEy, History of THE UNITEd States ARmy $81-92$ (1967).

23. See Kates, supra note 3, at 214-15. Even today, federal law continues to classify the entire able-bodied male citizenry aged $17-44$ as the unorganized militia of the United States. 10 U.S.C. $\S 311$ (1982). Men in this age group are subject to call-up in times of rebellion or other dire national emergency (for example, to maintain order and carry out policing in case of atomic attack) or if the National Guard is federalized and sent overseas along with the greater part of the Army as occurred during World War II. See Kates, supra note 3, at $271-72$.

24. Although some early state constitutions guarantee a right to arms for "common defense," they are necessarily not guaranteeing a state's right nor are they differentiating individual selfdefense against criminals from community defense by an organized military force. Rather, what they are expressing is the common law concept that an individual serves the entire community when he kills a felon who was attacking him, but only serves his private interests (and disserves those of the community generally) when he kills another citizen who has attacked him in the course of a private quarrel. This concept is the source of the common law distinction, which is so foreign to us, between "justifiable" homicide and "excusable" or se defendendo homicide (i.e., in the course of a private quarrel). Unlike the justifiable killing of a felon which served the entire community, homicide se defendendo was viewed as a tragedy: the killing of one good citizen by another. Killings in private, then, as opposed to the common defense, were viewed askance and the privilege of homicide se defendendo was hedged around with special restrictions. Hawkins explained the rationale as follows: Even though the decedent may have both started the fight and subsequently escalated to deadly force, "where the law judges a man guilty of homicide se defendendo, there must be some precedeni quarrel in which both parties always are, or at least may justly be supposed to have been, in some fault . . . . $1 \mathrm{~W}$. Hawkins, a Treatise of the Pleas of the Crown ch. 28, 824 (T. Leach 7th ed. 1795). Presuming that private self-defense implied at least partial initial fault by the defender. the law required him to have retreated literally to the point where he could retreat no further. Even then his homicide was classified as "excusable" not "justifiable." The perpetrator suffered forfeiture of all 
Since citizens would depend upon the same kinds of weaponry for performing all three functions (individual defense, military defense, and law enforcement) of what the Founders saw as an integral whole, the arms contemplated by the amendment are such as are suitable for all three functions. Thus, the amendment does not contemplate civilian possession of specialized military weaponry that is obviously not adapted even to the police function, much less to individual self-defense. Similarly excluded from the amendment's guarantee are things like brass knuckles, slug shots, straight razors, sawed-off long guns, and most "Saturday Night Specials." Whatever value such weapons may have for personal defense, they are not standard police or military weapons. ${ }^{25}$

\section{Permits and Registration}

Colonial and subsequent militia law required virtually every male of military age to appear periodically with his arms for inspection. ${ }^{26}$ Therefore, my Michigan article concluded that gun registration and licensing are not per se repugnant to the second amendment. ${ }^{27}$ So long as the purpose and intent is not to restrict or diminish the availability of firearms to the virtuous citizenry-and so long as such requirements are structured so as not to unduly burden or restrict that access ${ }^{28}$ - the second amendment allows arms registration and licensing.

his goods and was (as a matter of form only) sentenced to death, but was automatically entitled to pardon. Cf. E. CoKE, 3 Institutes 55, 56 (1797), distinguishing private self-defense from justifiable homicide:

As if a thiefe offers to rob or murder B either abroad, or in his home and thereupon assault him, and he defends himselfe without giving any back, and in his defense killeth the thiefe, this is no felony; for a man shall never give way to a thiefe, \& $\mathrm{c}$. Neither shall he forfeit any thing.

See also 1 E. East, Pleas of the Crown 271-72, 279-80 (1803).

By the late 1700's, this centuries-old disapprobation for "self-defense" was obsolescent. The attitudes of Blackstone, Locke, and Sidney, which were almost universally accepted in the colonies, see supra note 16 , found expression in the explicit recognition in many early state constitutions of the citizens' right to bear arms "in defense of themselves," but 18th-century law often still conceptualized self-defense as prevention of felony, just as lawyers today commonly employ the shorthand phrase "self-defense" to encompass the set of legal principles which also includes the right to use deadly force for the prevention of felony.

25. As to "Saturday Night Specials," the inherent ambiguity of the phrase (and the tendency of some to so label all handguns in advocating their prohibition) prompts me to define more closely my terms. The only handguns I believe excluded from the amendment's definition of arms would be cheaply made and of .25 or lower caliber-weapons which would not meet the procurement standards of most, if any, military establishments. See Kates, supra note 3, at 258-60.

26. Id. at 215-16.

27. See id. at 264-66. This conclusion validates only so-called mandatory licensing systems in which licensure is a matter of right for every responsible, adult applicant-criminal record or similar individual unfiness being the only ground for denial. In contrast, so-called permissive licensing systems, under which police enjoy broad discretion to deny permits (for instance) for the purpose of reducing the availability of firearms, are plainly inconsistent with the amendment, which guarantees arms possession as a matter of right. See infra note 33 and accompanying text.

28. See supra note 17 and accompanying text. No less than in the freedom of assembly context, determination of applications to possess a firearm for self-defense is obviously a matter "in which the clement of timeliness may be important." Carroll v. President \& Comm'rs of Princess Anne, 393 U.S. 175,182 (1968). Equally obviously, the delays of up to six months to which applicants for handgun permits are regularly subjected in New Jersey-much less, the two-year delay which used to be standard in New York City-cannot be justified on the grounds of inadequate police resources to 


\section{Carrying Firearms}

My Michigan article took the position that the right to bear arms off one's own premises (though no less "individual" than the right to keep them in the home) extended only to individuals carrying them in the course of militia service. ${ }^{29}$ This conclusion was based upon a historical/linguistic analysis which I leave to Professor Halbrook's reply, since I must concede that his evidence invalidates my position. Nothing in Professor Halbrook's linguistic evidence, however, gainsays the fact that, from early common law, the right to carry arms abroad was not absolute-as was the right to possess ordinary arms in the home. A statute of Edward II, reenacted in the time of Richard II, seems to have forbidden both the carrying of arms abroad in general and the carrying of them into particular places, such as courtrooms and Parliament. ${ }^{30}$ This common law tradition would suggest the validity of the many substantially similar American gun controls.

\section{IV \\ Conclusion}

I do not mean to imply that the second amendment would allow an unqualified prohibition of the bearing of arms outside one's own premises. At the very least the right to "keep" arms implies some right to carry them, for example, to and from a target range. ${ }^{31}$ Moreover, since the right to "bear" is also guaranteed, some more general right to carry must be contemplated. This reading does not necessarily render invalid the present American legal pattern which conditions carrying either on the weapon being unconcealed or on the possession of a carry permit. ${ }^{32}$ What it does imply, however, is very substantial limitations on the arbitrariness with which permit applications have traditionally been handled. At the very least, police agencies are not free either to limit permits to the wealthy, influential, or politically powerful, or to categorically deny them to all persons. ${ }^{33}$

process applications speedily. The least that is required when government subjects the exercise of a constitutional right to licensure is celerity of processing to assure that the licensing process will never materially impede the right's exercise.

29. See Kates, supra note 3, at 267.

30. Statute of Northhampton, 2 Edw. 3, ch. 3 (1328); 20 Rich. 2, ch. 1 (1396).

31. Kates, supra note 3 , at 267.

32. See, e.g. Tex. Penal Code Ann. \$ 46.02(a) (Vernon 1974) (handgun may not be carried concealed or openly); Miss. CoDE ANN. \$97-37-1 (1972) (concealed handgun prohibited); CAL. Penal Code $\$ 12025$ (West 1970) (concealed handgun prohibited without permit), § 12031 (carrying fircarm loaded on streets or in certain public buildings prohibited without permit).

33. The manner in which handgun permit laws have traditionally been administered makes more explicable the almost hysterical execration with which Professor Halbrook and other NRA partisans greet such schemes. The most notorious example is the law of New York City, where it has been impossible since at least the late 1930's for anyone lacking special influence to secure a carry permit. M. Ernst, The Ultimate Power 198 (1937). As of mid-1981, permit holders consisted of "entertainers, publishers, media stars, [and] politicians of all stripes," according to reporters who reviewed the permit list after New York courts required the police to divulge it. Included were the publisher of the New York Times and several other prominent advocates of federal permissive licensing (which would, like New York's law, affect only persons less influential than themselves). Kates, supra note 3, at 208; see also Kates, Handgun Baming in Light of the Prohibition Experience. in 
Firearms and Violence: Issues of Public Policy 154-55 (D. Kates ed. 1984) (discussing the corrosive effect of such revelations upon the enforceability of gun controls).

Although little information is available regarding permit administration in most other areas of the country, what few statistics can be gathered are not easy to reconcile with ordinary notions of rationality-much less with principles applicable to government activity affecting the exercise of a constitutional right. Why, for instance, are gun carry permits issued to one out of every 105 residents of Pittsburgh, Pennsylvania, but only one out of every 65,900 San Franciscans? It cannot be because San Franciscans are less menaced by violence, since Pittsburgh's violent crime rate is only a little over $20 \%$ of San Francisco's. Nor does it seem likely that Pittsburgh boasts 628 times as many citizens as San Francisco who have good character and are competent in firearms use. Statistics available for other areas exhibit the same wildly disparate pattern of permit decisionmaking: the state of Washington, one permit holder per every 61 residents; Palm Beach County, Florida, one in 291; (neighboring) Dade County, Florida, one in 1741; Denver, Colorado, one in 900.7; Minneapolis, Minnesota, one in 2696. (Permit figures were obtained from the Allegheny (Pennsylvania) County Sheriff's Department, San Francisco Police Department, Washington State Department of Licensing, Palm Beach County Sheriffs Office, Dade County Sheriffs Office, Denver Police Department, and Minnesota Police Department, respectively, and are documented by letters or newspaper articles on file with the author.) 